\title{
Effect Of Haemodialysis On Intra Dialytic Calcium, Phosphorus, Magnesium, Levels In Relation To Autonomic Nervous System Activity
}

\author{
Mona Hosny, Sahar Shawky, Ahmed Ramadan, Hany Refaat \\ and Walid Bischary \\ Internal Medicine Departement, Ain Shams University.
}

\begin{abstract}
Autonomic nervous system dysfunction is common in uremia and in patients under hemodialysis.

Changes in serum calcium, serum phosphorus and serum magnesuim always occur during hemodialysis. The relation between these changes and autonomic nervous system activity during hemodialysis has not been fully studied.

This study was carried out on 30 patients with chronic renal failure on regular hemodialysis with nearly similar age group. We measured serum calcium, serum phosphorus and serum magnesium throughout the session (at predialysis state, middialysis state: after 2 hours of the session and postdialysis: at the end of the hemodialysis Session). We have also assessed autonomic function (sympathetic by cold pressor test and parasympathetic by Valsalva maneuver test). Autonomic function tests were assessed at predialysis state, middialysis state and postdialysis state.

Calcuim level uncreased throughout the session $(\mathrm{P}<0.05)$, phosphorus leuel and Magnesium levels decreased, $(\mathrm{P}<0.001)$ and $(\mathrm{P}<0.05)$, throghout session .

As reguards parasympathetie dysfunetion, there was a significamt relation $(\mathrm{P}<0.05)$ with calcuim changes at predialytic and post dialytic states, a highly significant relation $(\mathrm{P}<0.001)$ with phosphorus and $(\mathrm{P}<0.05)$ with magnesiun, both at predialysis states.

Concerging sympathetie dysfunction, there was a significant relation $(\mathrm{P}<0.05)$ with calcium levels at end of session. There was a signifcant relation $(\mathrm{P}<0.05)$ with predialytic and postdialytic phosphorus levels .There was also significant relation $(\mathrm{P}<0.05)$ with predialytic magnesium level.
\end{abstract}

\section{Introduction}

The autonomic nervous system (A.N.S) is involved in adaptation to environmental changes. . The A.N.S. is functionally distinguished in sympathetic and parasympathetic pathways. (Mosqueda Garcia, 1996).

Autonomic nervous system dysfunction is a common feature in uremia and may have a number of clinical sequelae (The National Kidney Foundation, Inc 2001).

The kidneys have a dense afferent sensory and efferent sympathetic innervations. Therefore, they can be origin as well as target of overactivirty of the sympathetic nervous system (Rump. et al .,2000). It has been convincingly shown that patients with compensated renal failure (Litenberg et al.,1999) and patients undergoing hemodialysis treatement (Converse et al., 1992) exhibit sustained activation of the sympathetic nervous system, which contributes to hypertension and increased cardiovascular morbidity and mortality (Zoccali et al.,2002).

In dialysis patients, elevated levels of phosphate and calcium times phosphate $(\mathrm{Ca}$ $\mathrm{x} P$ ) ion product are associated with extraskeletal calcifications, as well as an increased risk of death. Cardiovascular califications may possibly be related to the high cardiovascular mortality seen in dialysis patients (Gallieni et al., 2002).

Renal failure is the most common clinical disorder associated with hypermagnesemia (Moutokalakis,1990). 
Magnesium competitively inhibits calcium Influx into presynaptic nerve terminals, and increasing the threshold of axonal excitation, decreasing nerve conduction velocity (Rude and Oldham, 1990).

\section{Patients and Methods}

30 patients with chronic renal failure were randomly chosen from Ain Shams University hospital, nephrology department, dialysis units and from Ain Shams Specialied hospital, dialysis unit. There were 15 males and 15 females with nearly similar age group.

All patients had been used to do 4 hours hemodialysis sessions, 3 times weekly using the same type of dialyzer (Polysulfon). All patients had used bicarbonate dialysate with the same concentration of calcium, magnesium, potassium, chloride and sodium,

\section{The dialsate properties were:}

- Formula for 1 liter of diluted dialysate

Sodduim 105meq Magnesuim 1meq Potassuim $2 \mathrm{meq}$ Chloride $111 \mathrm{meq}$ Calcuim $1.7 \mathrm{meq} \quad \mathrm{CH} 3 \mathrm{COO} \quad 3.0 \mathrm{meq}$ - 36 meq sodium bicarbonate is added before use.

- Dialysate preserved at a temperature $>4$ ${ }^{0} \mathrm{C}$

The following patients were excluded from the study:

- Diabetic patients

- Other patients with diseases that may affect the A.N.S. such as: chronic liver disease, sarcoidosis and autoimmune diseases.

- Patients with ischemic heart diseases

- Patients with coronary artery disease (recent and previous).

All patients were subjected to the following

We have done the follouring measurements at predialysis state, $2 \mathrm{hrs}$ after beginning of session and at postdialysis state:-

1. Serum Calcuim level

2. Serum phosphorus level

3. Serum magnesium level
4. Test of parasympathetic function ( Valsalva maneuver)

5. Test of Sympathetic function ( Cold pressor test).

\section{Methods}

Serum calcium measurement by colorimetric method (Young D, et al.,1975) this method is used for quantitative determination of calcium in serum.

\section{Principle}

Arsenazo III specially binds to calcium forming a coloured complex which can be measured at $650 \mathrm{~nm}$.

$\mathrm{Ca}^{++}+$arsenazo $\mathrm{III} \rightarrow$ coloured complex. The amount of the Calcium present in the sample is directly proportional to the intensity of the coloured complex formed.

- Serum samples were collected and stored at +2 to $+8{ }^{\circ} \mathrm{c}$

- Mix $15 \mathrm{ul}$ of sample and $1 \mathrm{ml}$ of reagent

- Mix $15 \mathrm{ul}$ of calibrator and $1 \mathrm{ml}$ of reagent

- Mix 15 ul of distilled water and $1 \mathrm{ml}$ reagent to get the reagent blank.

- Read the absorbance of the sample (Asample) and calibrator (A calibrator) against reagent blank after 5 minutes.

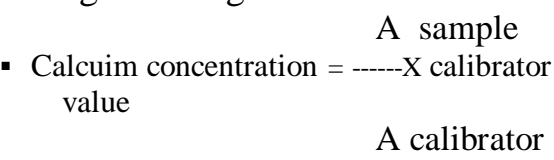

- Normal values

$$
\begin{aligned}
& \text { Adults } \quad 2.05-2.54 \mathrm{mmol} / \mathrm{l} \\
& (8.2-10.2 \mathrm{mg} / \mathrm{dl})
\end{aligned}
$$

Sensitivity: the minimum detectable level has been determined as $0.25 \mathrm{mmol} / \mathrm{l}$.

2) Serum phosphorus measurement by calorimetric method (Kesler G. et al ., 1964, Young D.S. et al.,1975)

Principle

Inorganic phosphate reacts with sodium molybdate forming a phosphomolybdate complex. Its subsequent reduction in alkaline medium originates a blue molybdenum complex. The intensity of the colour formed is proportional to the amount of phosphorus present in the sample.

- Serum samples collected were stable for at least7 days at $2-8^{0} \mathrm{c}$. Mix $100 \mathrm{ul}$ of sample and $3 \mathrm{ml}$ of working reagent. 
Mix $100 \mathrm{ml}$ of standard and $3 \mathrm{ml}$ of working reagent. Incubate for 10 minutes at $37^{\circ} \mathrm{c}$. Measurement of the absorbance of the unknown and standard against blank reagent at 110 $\mathrm{nm}$. The co/our is stable for at least 2 hours (630-750nm).

serum phosphours $(\mathrm{mg} / \mathrm{dl})=$

Abs. unknown

------- x conc. standard

Abs. standard

- Normal values of phosphorus in adults= $2.5-5.0 \mathrm{mg} / \mathrm{dl}$

Seruum magnesuim measurement by xylidyl blue calorimetric method. (Bohuon,C,1962)

Principle

In an alkaline meduim, the magnesium ions of the sample will produce a colored complex with xylidyl blue. Colour intensity is directly proportional to the magnesium ions concentration present in the sample. Glycol- etherdiaminentetracetic acid (GEDTA) performs as a chelating agent.

Non- hemolyzed serum samples are used. Serum magnesuim is stable for up to 5-7 days at 2-8 $\mathrm{c}$.

Mix $0.02 \mathrm{ml}$ of standard solution with $2 \mathrm{ml}$ of reagent . Mix $0.02 \mathrm{ml}$ of sample with $2 \mathrm{ml}$ of reagent. Mix well and let stand $10 \mathrm{~min}$ at room temperatrure $\left(20-25^{\circ} \mathrm{c}\right)$. Measurement of the absorbance of sample and standard against blank reagent at wavelength $546 \mathrm{~nm}, 520 \mathrm{~nm}$.

S.A.O.D.
- Magnesium $(\mathrm{mg} / \mathrm{dl})=-$--.T.O.D
S.--- 4

Normal values :

Results

Table 1 :comparaison between serum calcium levels during hemodialysis session at the following conditions : predialysis, after 2 hours of the session and postdialysis .
Serum magnesium $=1.8-2.6 \mathrm{mg} / \mathrm{dl}$ Valsalua manosuver(test of parasympathetic function ).

The maneuver is performed by attempting to forcibly exhale while keeping the mouth and nose closed .

The maneuver is based on the fact that when patient forcibly exhales against a closed nose and mouth while bearing down for 30 seconds, specific changes occur in blood returning to the heart .

\section{A) normal response:}

1. Firstly : blood pressure drops, with loss of venous return to the heart and the heart rate rises( $>90$ beats $/ \mathrm{mn}$ ).

2. When the intrathoracic pressure increase is released, the blood pressure overshoots because of continued sympathetic drive and the heart rate drops helow the basal level due to baroreflex activation

B) abnormal response (parasympathetic dysfunction )

1. abolishment of the $2^{\text {nd }}$ blood pressure over shooting .

2. abolishment of the associated reflex bradycardia ( Fuller G,2000; Dnaghy M.,2001)

Cold pressor test ( test of sympathetic function ) cold pressor test was conducted by immersing the patient dominant hand into cold water ( $<4$ degrees ) for 2 minutes.

A) Normal response

Blood pressure rises from the basal level after doing the procedure .

B) Abnormal response

Faiure of the blood pressure rising ( How P.A, 1997 ).

\begin{tabular}{|l|c|c|c|}
\hline & & Serum phosphorus ( in mg /dl) & Postdiqlysis \\
\hline & Predialysis & after 2 hours of the session & $9.40 \pm 1.10$ \\
\hline Mean \pm SD (in mg/d) & $8.10 \pm 1.07$ & $9.08 \pm 1.17$ & 6.35 \\
\hline Anova (F) & & & \\
\hline
\end{tabular}


Table 2 :comparaison between serum phosphorus levels during hemodialysis session at the following conditions : predialysis, after 2 hours of the session and postdialysis

\begin{tabular}{|l|c|c|c|}
\hline & \multicolumn{3}{|c|}{ Serum phosphorus (in mg/dl) } \\
\hline & Predialysis & $\begin{array}{c}\text { After 2 hours of the } \\
\text { session }\end{array}$ & Postdialysis \\
\hline $\begin{array}{l}\text { Mean } \pm \text { SD ( in mg/dl } \\
\text { Anova (f) }\end{array}$ & $6.16 \pm 1.72$ & $4.05 \pm 1.75$ & $3.70 \pm 1.32$ \\
\hline Pvolue & & 20.63 & $<0.001$ \\
\hline
\end{tabular}

Table 3: comparaison between serum magnesium levels during hemodialysis session at the following conditions : predialysis, after 2 hours of the session and postdialysis.

\begin{tabular}{|c|c|c|c|}
\hline & \multicolumn{3}{|c|}{ "Serum magnesium ( in mg/dl) } \\
\hline & Predialysis & $\begin{array}{l}\text { After } 2 \text { hours of the } \\
\text { session }\end{array}$ & Postdialysis \\
\hline Mean \pm SD ( in $\mathrm{mg} / \mathrm{dl})$ & $2.81+0.43$ & $2.61 \pm 0.41$ & $2.53+0.38$ \\
\hline Anova (f) & \multicolumn{3}{|c|}{3.89} \\
\hline Pvolue & \multicolumn{3}{|c|}{$<0.05$} \\
\hline
\end{tabular}

Table 4: comparaison of parasympathetic function changes( using valsalva maneuver ) during hemodialysis at the following conditions : predialysis, after 2 hours of the session and postdialysis.

\begin{tabular}{|c|c|c|c|c|}
\hline & & \multicolumn{3}{|c|}{ Valsalva maneuuver } \\
\hline & & Predialysis & $\begin{array}{l}\text { After } 2 \text { hours of the } \\
\text { session }\end{array}$ & Postdialysis \\
\hline \multirow[t]{2}{*}{$\begin{array}{ll}\text { No } & \text { of } \\
\text { patients } & \\
\end{array}$} & $\begin{array}{l}\text { Normal } \\
\text { response }\end{array}$ & $26(86.7 \%)$ & $24(80.0 \%)$ & $23(76.7 \%)$ \\
\hline & $\begin{array}{l}\text { Abnormal } \\
\text { response }\end{array}$ & $4(13.3 \%)$ & $6(20 \%)$ & $7(23.3 \%)$ \\
\hline \multicolumn{2}{|c|}{ Chi - square $(x 2)$} & \multicolumn{3}{|c|}{1.02} \\
\hline \multicolumn{2}{|l|}{ Pvolue } & \multicolumn{3}{|c|}{$>0.05$} \\
\hline
\end{tabular}

Table 5: comparaison of sympathetic function changes ( using cold pressor test ) during hemodialysis at the following conditions : predialysis, after 2 hours of the session and postdialysis.

\begin{tabular}{|c|c|c|c|c|}
\hline & & \multicolumn{3}{|c|}{ Cold pressor test } \\
\hline & & Predialysis & $\begin{array}{l}\text { After } 2 \text { hours of the } \\
\text { session }\end{array}$ & Postdialysis \\
\hline \multirow[t]{2}{*}{$\begin{array}{ll}\text { No of } \\
\text { patients }\end{array}$} & $\begin{array}{l}\text { Normal } \\
\text { response }\end{array}$ & $26(86.7 \%)$ & $24(80.0 \%)$ & $23(76.7 \%)$ \\
\hline & $\begin{array}{l}\text { Abnormal } \\
\text { response }\end{array}$ & $4(13.3 \%)$ & $6(20 \%)$ & $5(16.7 \%)$ \\
\hline \multicolumn{2}{|c|}{ Chi - square (x2) } & & 0.48 & \\
\hline
\end{tabular}


Table 6 : relation between serum calcium levels and parasympatheetic function changes ( using valsalva maneuver ):

\begin{tabular}{|l|l|c|c|c|}
\hline \multicolumn{2}{|c|}{ Valsalva maneuver } & \multicolumn{1}{c|}{ Serum calcium } \\
\hline \multirow{2}{*}{ No of the patients } & $\begin{array}{l}\text { Abnormal } \\
\text { response }\end{array}$ & Predialysis & $\begin{array}{c}\text { After 2 hours of the } \\
\text { session }\end{array}$ & Postdialysis \\
\cline { 2 - 5 } & Normal response & 4 & 6 & 7 \\
\hline $\begin{array}{l}\text { Mean + SD ( in } \\
\text { mg/dl })\end{array}$ & $\begin{array}{l}\text { Abnormal } \\
\text { response }\end{array}$ & $7.45 \pm 0.49$ & 24 & 23 \\
\cline { 2 - 6 } & Normal response & $8.55 \pm 1.06$ & $8.57 \pm 1.35$ & $9.67 \pm 1.0 .83$ \\
\hline Pvalue & & $<0.05$ & $9.20 \pm 1.12$ & $<0.05$ \\
\hline
\end{tabular}

Table 7 : relation between serum phosphorus levels and parasympathetic function changes ( using valsalva maneuver) during hemdialysis at the following conditions: predialysis, after 2 hours of the session and postdialysis

\begin{tabular}{|l|l|c|c|c|}
\hline \multicolumn{2}{|l|}{} & \multicolumn{2}{c|}{ Serum phosphorus } \\
\hline Valsalva maneuver & Predialysis & After 2 hours of the session & Postdialysis \\
\hline \multirow{3}{*}{ No of the patients } & $\begin{array}{l}\text { Abnormal } \\
\text { response }\end{array}$ & 4 & 6 & 7 \\
\cline { 2 - 5 } & Normal response & 26 & 24 & 23 \\
\hline \multirow{2}{*}{ Mean + SD (in mg/dl ) } & $\begin{array}{l}\text { Abnormal } \\
\text { response }\end{array}$ & $8.85 \pm 1.61$ & $4.55 \pm 2.49$ & $4.11 \pm 1.25$ \\
\cline { 2 - 5 } & Normal response & $5.75 \underline{ \pm 1.34}$ & $3.93 \pm 1.58$ & $3.57 \pm 1.33$ \\
\hline Pvalue & $<0.001$ & $>0.05$ & $>0.05$ \\
\hline
\end{tabular}

Table 8 : relation between serum mangnesium levels and parasympathetic function changes ( using valsalua maneuver ) during hemodialysis at the following conditions : predialysis, after 2 hours and postdialysis .

\begin{tabular}{|l|l|c|c|c|}
\hline \multicolumn{2}{|l|}{} & \multicolumn{3}{|c|}{ Serum magnesium } \\
\hline \multicolumn{2}{|l|}{ Valsalva maneuver } & Predialysis & $\begin{array}{c}\text { After 2 hours of the } \\
\text { session }\end{array}$ & Postdialysis \\
\hline & $\begin{array}{l}\text { Abnormal } \\
\text { response }\end{array}$ & 4 & 6 & 7 \\
\cline { 2 - 5 } & Normal response & 26 & 24 & 23 \\
\hline \multirow{2}{*}{ Mean \pm SD $($ in $\mathrm{mg} / \mathrm{dl})$} & $\begin{array}{l}\text { Abnormal } \\
\text { response }\end{array}$ & $3.33 \pm 0.31$ & $2.72 \pm 0.53$ & $2.73 \pm 0.42$ \\
\hline
\end{tabular}




\begin{tabular}{|l|c|c|c|c||}
\hline & Normal response & $2.74 \pm 0.39$ & $2.58 \pm 0.39$ & $2.47 \pm 0.35$ \\
\hline Pvalue & $<0.05$ & $>0.05$ & $>0.05$ \\
\hline
\end{tabular}

Table 9: relation between serum calcium levels and sympathetic function changes ( using cold pressor test ) during hemodialysis session at the following conditions : predialysis, after 2 hours of the session and postdialysis

\begin{tabular}{|c|c|c|c|c|}
\hline & & \multicolumn{3}{|c|}{ Serum calcium } \\
\hline \multicolumn{2}{|l|}{ Cold pressor test } & Predialysis & $\begin{array}{l}\text { After } 2 \text { hours of the } \\
\text { session }\end{array}$ & Postdialysis \\
\hline \multirow{2}{*}{ No of the patients } & $\begin{array}{l}\text { Abnormal } \\
\text { response }\end{array}$ & 4 & 6 & 5 \\
\hline & Normal response & 26 & 24 & 25 \\
\hline \multirow{2}{*}{$\underset{\mathrm{mg} / \mathrm{dl})}{\operatorname{Mean}} \pm \mathrm{SD}$ ( in } & $\begin{array}{l}\text { Abnormal } \\
\text { response }\end{array}$ & $8.28+0.97$ & $8.42 \pm 1.50$ & $8.16 \pm 0.41$ \\
\hline & Normal response & $8.42 \pm 1.90$ & $9.24 \pm 1.05$ & $9.66 \pm 1.03$ \\
\hline \multicolumn{2}{|l|}{ Pvalue } & $>0.05$ & $>0.05$ & $<0.05$ \\
\hline
\end{tabular}

Table 10 :relation between serum phosphorus levels and sympathetic function changes (using cold pressor test ) during hemodialysis session at the following condition :predialysis, after 2 hours of the session and postdialysis.

\begin{tabular}{|c|c|c|c|c|}
\hline & & \multicolumn{3}{|c|}{ Serum phosphorus } \\
\hline \multicolumn{2}{|l|}{ Cold pressor test } & Predialysis & After 2 hours of the session & Postdialysis \\
\hline \multirow{2}{*}{ No of the patients } & $\begin{array}{l}\text { Abnormal } \\
\text { response }\end{array}$ & 4 & 6 & 5 \\
\hline & Normal response & 26 & 24 & 25 \\
\hline \multirow{2}{*}{$\begin{array}{l}\text { Mean } \pm \text { SD ( in } \\
m g / d l)\end{array}$} & $\begin{array}{l}\text { Abnormal } \\
\text { response }\end{array}$ & $8.15 \pm 1.49$ & $4.47 \pm 2.11$ & $5.10 \pm 1.48$ \\
\hline & Normal response & $5.86+1.57$ & $3.95 \pm 1.67$ & $3.40 \pm 1.10$ \\
\hline \multicolumn{2}{|l|}{ Pvalue } & $<0.05$ & $>0.05$ & $<0.05$ \\
\hline
\end{tabular}

Table 11: relation between serum magnesium levels and sympathetic function changes ( using cold pressor test ) during hemodialysis session at the following conditions : preddialysis , after 2 hours of the session and postdialysis.

\begin{tabular}{||l|l|c|c|c|}
\hline \multicolumn{2}{|l|}{} & \multicolumn{2}{|c|}{ Serum magnesium } \\
\hline \multicolumn{2}{||l|}{ Cold pressor test } & Predialysis & After 2 hours of the session & Postdialysis \\
\hline No of the patients & $\begin{array}{l}\text { Abnormal } \\
\text { response }\end{array}$ & 4 & 6 & 7 \\
\cline { 2 - 5 } & Normal response & 26 & 24 & 25 \\
\hline Mean \pm SD $($ in $\mathrm{mg} / \mathrm{dl})$ & $\begin{array}{l}\text { Abnormal } \\
\text { response }\end{array}$ & $3.30 \pm 0.2$ & $2.77 \pm 0.50$ & $2.58 \pm 0.53$ \\
\hline
\end{tabular}




\begin{tabular}{|l|c|c|c|c|}
\hline & Normal response & $2.74 \pm 0.40$ & $2.57 \pm 0.39$ & $2.52 \pm 0.36$ \\
\hline Pvalue & $<0.05$ & $>0.05$ & $>0.05$ \\
\hline
\end{tabular}

Table 12 : relation between parasympathetic function changes ( using valsalva maneuver ) and duration of dialysis (in years ).

\begin{tabular}{|c|c|c|c|c|}
\hline & & \multicolumn{3}{|c|}{ Valsalva maneuver } \\
\hline \multicolumn{2}{|c|}{ Duration of dialysis (in years) } & Predialysis & After 2 hours of the session & Postdialysis \\
\hline \multirow{2}{*}{ No of the patients } & $\begin{array}{l}\text { Abnormal } \\
\text { response }\end{array}$ & 4 & 6 & 7 \\
\hline & Normal response & 26 & 24 & 25 \\
\hline \multirow{2}{*}{$\underset{\mathrm{mg} / \mathrm{dl})}{\operatorname{Mean}} \pm \mathrm{SD}$ ( in } & $\begin{array}{l}\text { Abnormal } \\
\text { response }\end{array}$ & $6.00 \pm 3.37$ & $4.50 \pm 2.43$ & $5.71 \pm 4.54$ \\
\hline & Normal response & $5.26 \pm 3.60$ & $5.57 \pm 3.75$ & $5.25 \pm 3.27$ \\
\hline \multicolumn{2}{|l|}{ Pvalue } & $>0.05$ & $>0.05$ & $>0.05$ \\
\hline
\end{tabular}

Table 13 : relation between sympathetic function changes ( using cold pressor test ) and duration of dialysis ( in years ).

\begin{tabular}{|l|l|c|c|c|}
\hline & \multicolumn{2}{|c|}{ Cold pressor test } \\
\hline Duration of dialysis (in years) & $\begin{array}{l}\text { Pbnormal } \\
\text { response }\end{array}$ & 4 & After 2 hours of the session & Postdialysis \\
\cline { 2 - 5 } & Normal response & 26 & 6 & 5 \\
\hline $\begin{array}{l}\text { Mean the patients } \pm \operatorname{SD}(\text { in } \\
\text { mg/dl })\end{array}$ & $\begin{array}{l}\text { Abnormal } \\
\text { response }\end{array}$ & $6.00 \pm 4.55$ & 24 & 25 \\
\hline & Normal response & $5.26 \pm 3.44$ & $7.33 \pm 4.46$ & $6.80 \pm 4.60$ \\
\hline Pvalue & & $>0.05$ & $4.86 \pm 3.17$ & $5.07 \pm 3.30$ \\
\hline
\end{tabular}

\section{Discussion}

In published studies of chronic hemodialysis patients, the frequency of autonomic dysfunction vary widely. One reason of the variation may be the time of testing with respect to time of dialysis (Rosansky et al .,1995) .

The relationship between intradialytic changes in serum calcium, serum phosphorus and serum magnesium, and its effects on autonomic nervous system has not been to our knowledge previously understood.

In our study, there was a significant increase $(\mathrm{p}<0.05$ )in calcium level, when measured prior to dialysis (at predialysis state) $(8.10 \pm 1.07 \mathrm{mg} / \mathrm{dl})$, after 2 hours $(9.08 \pm 1.17 \mathrm{mg} / \mathrm{dl})$ and postdialysis $(0.40 \pm 1.1 \mathrm{mg} / \mathrm{dl}),($ table1 $)$ This was due to calcium flux from dialysate to patients 
blood as there was a hypocalcemic level prior to dialysis $(8.10 \pm 1.07 \mathrm{mg} / \mathrm{dl})$. the continuous increase in calcium level throughout session agrees with Argiles, (1995)

In table 2, there was a significant decrease in phosphorus level between predialysis state and mid session state (after 2 hours $),(p<0.05)$. There was a more significant decrease in phosphorus level between mid session state (after 2 hours) and post dialysis state $(\mathrm{p}<0.05)$. the highest significant decrease was between predialysis and postdialysis states $(\mathrm{p}<0.001)$ by Anova test. The steady decrease in phosphorus level throughout the session agrees with Man N.K, et al.,(2001), who stated that phosphate removal is highest in the first one to two hours of session. However, our study doesn't agree with the study done by Cioffi et al.,(2002), who supports postdialytic rebound in serum phosphorus and also with the study conducted by De Soi and Umans, (1993), who found that although phosphate removal continued for the duration of dialysis, serum phosphorus did not continue to decrease, either reaching an apparently steady state or beginig to rebound even during dialysis.

In (table3), there was a significant decrease in Magnesium levels between predialysis, midsession (after2hours) $(2.61 \pm 0.41 \mathrm{mg} / \mathrm{dl})$ and postdialysis state $(2.53 \pm 0.38 \mathrm{mg} / \mathrm{dl})$ as $(\mathrm{p}<0.05)$ by Anova test. There was a continuous significant fall of magnesium throughout the session and this agrees with Krachler et al .,(2000), who conducted a study supporting the decrease in serum magnesium throughout the session , probably due to continuous removal or filtration of magnesium from blood to dialysate.

In (table 4 and5), we found an increase in the number of patients experiencing abnormal response to Valsalva maneuver ( parasympathetic dysfunction ) as the session progresses, while in comparaison the abnormal response to cold pressor test (sympathetic dysfuunction ) was fluctuating throughout the session, but these were to nonsignificant degrees $(p>0.05)$ wether parasympathetic or sympathetic function tests. This agrees with Litemburg et al ., (1996), who conducted a study on 22 patients with chronic renal failure under hemodialysis who were asked to perform autonomic function tests (static exercise tests, Valsalva maneuver and deep breathing test) at different moments of the hemodialysis procedure and found no significant change $(p>0.05)$ in autonomic function tests during the course of uncomplicated hemodialysis.

In (table 6), we found that at predialysis state, there was 4 patients out of 30 with abnormal valsalva maneuver (abolishment of the second blood pressure overshooting and abolishment of the associasted reflex bradycardia). There was a significant difference $(\mathrm{p}<0.05)$ of calcium level between them $(7.45 \pm 0.49 \mathrm{mg} / \mathrm{dl})$ and those patients with normal Valsalva response $(8.55+1.06 \mathrm{mg} / \mathrm{dl})$ and this means that calcium level mostly interferes with valsalva maneuver. After 2 hours of the session, (table 6), there were 6 patients out of 30 with abnormal Valsalva maneuver. There was a nonsignificant difference ( $p>0.05$ )in serum calcium levels between them $(8.57 \pm 1.35 \mathrm{mg} / \mathrm{dl})$ and those with normal Valsalva maneuver. This means that at midsession, rise in serum calcium level doesn't interfere with parasympathetic system dysfunction, despite of increasing of the number of patients with abnormal response. At postdialysis state, (table 6), the number of patients with abnormal Valsalva maneuver was 7 out of 30 . There was a significant difference $(p<0.05)$ between them $(8.67 \pm 0.83 \mathrm{mg} / \mathrm{dl})$ and those with normal Valsalva maneuver $(9.63 \pm 1.09 \mathrm{mg} / \mathrm{dl})$ as regards serum calcium , being higher in those with normal response. The increasing autonomic dysfunction throughout the session was associated with close increase in serum calcium level, wich implicates that the higher calcium level did not improve the percentage of patients having parasympathetic dysfunction.

In (table7), at predialysis state, there were 4 patients out of 30 with abnormal Valsalva maneuver and a high phosphorus level $(8.85 \pm 1.61 \mathrm{mg} / \mathrm{dl})$, being significantly higher $(p<0.001)$ than those with normal valsalva maneuver $(5.75 \pm 1.34 \mathrm{mg} / \mathrm{dl})$. At 
midsession ( after2 hours ),there were 6 patients out of 30 with abnormal Valsalva maneuver, their phosphorus level although lower than at predialysis state, was still higher than those with normal response but in a non significant way $(p>0.05)$. At postdialysis state, (table7), there were 7 patients out of 30 with abnormal Valsolva maneuver and still a more decreased level of serum phosphorus in a non significant way ( $p>0.05)$ as compared with those who had normal valsalva maneuver. This means that serum phosphorus level, (although decreasing throughout the session ), seems to play a significant role in autonomic dysfunction occurring throughout the session ( table 7).

In (table8), we found that at predialysis state, 4 pateints out of 30 with abnormal Valsalva maneuver had a high serum magnesium level $(3.33 \pm 0.3 \mathrm{mg} / \mathrm{dl})$ which was significantly higher $(p<0.05)$ them those patients with normal valsalva maneuver $(2.74 \pm 0.39 \mathrm{mg} / \mathrm{dl})$. After 2 hours of the session, the number of patients with abnormal valsalva maneuver increased to 6 out of 30. Their serum magnesium level, although lower than predialysis state, yet is nonsignificantly higher $(p>0.05)$ than those patients with normal valsalva maneuver ( table8 ). At postdialysis state ( table8 ),7patients out of 30 were having an abnormal valsalva maneuver and at the same time, their serum magnesium level was lower than 'mid dialysis state and still nonsignificantly higher $(p>0.05)$ than patients with normal Valsava maneuver. This means that serum magnesium level, although decreasing, yet there was an increase in the number of patients with autonomic dysfunction. This was only significant $(\mathrm{p}<0.05)$ at the start of the session (predialysis state).

As regards cold pressor test, at predialytic state, ther were 4 patients out of 30 with abnormal cold pressor test and with a nonsignificant difference of serum cacium level $(\mathrm{p}<0.05)$, from those patients with normal cold pressor test. ( table9). After 2 hours of the session, the number of patients with abnormal cold pressor test increased to 6 patients out of 30 they had an incease in serum calcium level which was nonsignificantly lower $(p>0.05)$ than those patients with normal cold pressor test ( table9) At post dialysis state, there were 5patients with abnormal cold pressor test with still increasing calcium level $(8.16 \pm 0.41 \mathrm{mg} / \mathrm{dl})$, but still significantly lower $(\mathrm{p}<0.05)$ than those patients with normal cold pressor test $(9.66+1.03 \mathrm{mg} / \mathrm{dl})$, (Table 9) This means that serum calcium level doesn,t affect much sympathetic function test throughout dialysis ( table9).

Changes in serum calcium during hemodialysis and its effect on autonomic nervous system was studied by Buda .et al., (2000), who concluded that hemodialysis leads to important change in the activity of both components of autonomic nervous system and the factors which may influence the quality of this response may be , among others, low total calcium ion concentration

At predialysis state, serum phosphorus level was high in 4 patients out of $30(8.15 \pm 1.49 \mathrm{mg} / \mathrm{dl})$ with abnormal cold pressor test, with significant difference $(<0.05)$ from those with normal cold pressor test $(5.86 \pm 1.57 \mathrm{mg} / \mathrm{dl})$, (table 10$)$. Abnormal high serum phosphrous at predialytic state could be a predisposing factor for abnormal sympathetic function . At midsession, (after2 hours of the session) the number of patients with abnormal cold pressor test increased to 6 out of 30, with a lower phosphorus level than predialysis state (table10), but still being non significantly higher $(p>0.05)$ than those with normal cold pressor test. This may be due to intradialytic exchange mechanisms during mid session

In (table 10), at postdialytic state, the number of patients with abnormal cold pressor test decreased to 5 out of 30 with still increasing serum phosphorus level $(5.10 \pm 1.148 \mathrm{mg} / \mathrm{dl})$, being higher than middialysis state. This may be a rebound level, being significantly higher, $(\mathrm{p}<0.05)$, than those with normal cold pressor test $(3.40+1.10 \mathrm{mg} / \mathrm{dl})$

In ( table 11), at predialytic state, 4 patients out of 30 with abnormal cold pressor test, had a higher serum magnesium level $(3.30 \pm 0.20 \mathrm{mg} / \mathrm{dl})$, being significantly higher $(\mathrm{p}<0.05)$ than those with normal cold pressor test. $(2.74 \pm 00.40 \mathrm{mg} / \mathrm{dl})$. 
At middialysis session (after 2 hours of the session), (table11), 6 patients out of 30 with abnormal cold pressor test had lower serum level of magnesium than predialysis state, but till non significantly higher, ( $p>0.05)$,than hose with normal cold pressor test. In (table 11), at postdialysis state ,5 patients out of 30 had abnormal cold pressor test. They also had a lower serum magnesium level than both predialytic and middialytic states, but still having a non significantly higher level than those with normal cold pressor test $(p>0.05)$. The increasing then decreasing number of patients with abnormal cold pressor test doesn't correlate with the initially high then consistently decreasing serum magnesium level, throughout the hemodialysis session. (table11) We have also studied the relation between the duration of dialysis treatement ( in years) and autonomic dysfunction (both sympathetic and parasympathetic), ( table 12 and 13) Mean \pm S.D. duration of dialysis (in years) of patients with abnormal response ( either by Valsalva maneuver or by cold pressor test ), showed non significant correlation $(p>0.05)$ with those patients with normal response to either Valsalva maneuver or cold pressor test. This means that duration of dialysis doesn't affect the presence or absence of autonomic dysfunction.

\section{Conclusion}

From our study, we concluded that:

Significant increase in serum calcium, highly significant decrease in serum phosphorus and significant decrease in serum magnesium occur throughout the hemodialysis session

There was no significant changes between autonomic function tests (sympathetic and parasympathetic) throughout the session

Significant correlation between parasympathetic dysfunction and predialytic serum calcium levels was present whereas sympathetic dysfunction correlated more with postdialytic levels.
Highly significant correlation between predialytic hyperphosphatemia and parasympathetic dysfunction with shift to nonsignificant correlation later in the session, with the drop in serum phosphorus. Significant correlation between predialytic hyper-magnesemia and autonomic dysfunction (both sympathetic and parasympathetic) with shift to nonsignificant correlation later in the session, with the drop in serum magnesium

\section{References}

1. Argiles I., Ciscort A., (1995): Points to remember when selecting calcium dialysate concentration. Nephrol.Dial.Transplant., 10:451-454.

2. Buda S., Stompor T., Sulowiez W., Kopec J. and Janion ,(2000): The impact of changes in the level of calcium, phosphate and magnesium during hemodialysis on outonomic system reactivity as measured by the heart rate variability analysis. Przegl Lek., 57(6):340345.

3. Cioffi M.,Iodice C., Minutolo P.R., Bellizi V., Di Iorio B.R., Giennettasio V.T., guiseppe Conte M.A. and De Nicola L., (2002): Postdialytie rebound of serum phosphorus ,: Pathogenetic and clinical insights.J.Am.Soc. Nephrol., 13:10461054.

4. Converse R.L., Jacobson T.N., Toto RD et al.,(1992): Synpathetic Oueractivirty in patients with chronic renal failure. N.Engl.J. Med., 327:1912-1918.

5. De Soi C.A. and Umans J.G., (1993): Phosphate Kinetics during high flux hemodolysis. Phosphate Kinetics during high flux nemodialysis. Journal of the American Society of Nephrology , Vol 4:1214-1218.

6. Donaghy M,(2001): Bruin's disease of the nervous system $11^{\text {th }}$ edition, Oxford University Press.

7. Fuller G., (2000): Neurological examination made easy, and edition. Harwnt publishers limited.

8. Gallieni M., Cucciniello E., Amaro E., Fatuzzo P., Gaggiotti A., Maringhini S., Rotolo U. and Brancaccio D., (2000): Calcuim, phoshate and PTM levels in the hemodialysis population: a multicenter study. J. Nephrol., 15(2): 165 - 170. 
9. Kesler G.et al., (1964) : Clin. Chem., 10:686.

10. Krachler M., S.charfetter H. and Winsberger G. H., (2000): Kinetics of metal cations magnesium, calcium, Copper, Zinc, Strontium, barium and lead in chronic hemodialysis patients. Clin. Nephrol., Jul, 54(1): 35-44.

11. Litenburg G.,P.J. Blan Kestijin, F.Boomsma and H.A. Koomans, (1996) : No change in autonomic funchion tests during uncomplicated hemodialysis. Nephrol. Dial. Transplant.

12. Litenburg G., Blan Kestyin P.J., Oey P.L. et al ., (1999): Reduction of sympathetic hyperactivity by enalapril in patients with chronic renal Failure. N.Engl . J.Med., 340:1321-1328.

13. Moue P.A, (1997): Clinical autonomic disorders: evaluation and management, second edition: PP199.

14. Mospueda- Garcia R., (1996): Central autonomic regulation, in Roberston D., how P.A., Polins Ky RJ.(eds) Primer of the autonomic nervous system (ed1). San Diego, C.A., Academic : PP3-12.
15. Moutokalakis T.D., (1990): Magnesuim metabolism in chronic renal failivre. Magnesium Resarch, 3:121-127.

16. Roasansky S.J., Rhinehart R., Whithman D.and Menachery S.J., (1995): Comparaison of autonomic function using Valsolua ratio and 30:15 Postural ratio prior to and after hemodialysis treatement. Clin . Auton. Res., Jun, 5 (3):151-154.

17. Rude R.K. and Olatham S.B., (1990): Disorders of magnesium metabolisin. The metabolic and molecular bosis of acqwried disease led. R.D. cohen, B.Leuris, K.G., M.M.Alberti and A.M. Denman),: PP1124. Balliere, hondon .

18. Rump L.C., Amann K., Orth S. and Ritz F., (2000): Sympathetic oueractivrty in renal disease: Aurindow to understand srogressior and carduoiascular complications of uremia. Nephrol. Dial . Transplant.; 15:1733-1738.

19. Young D. and Pastaner L.,(1975).clin . chem, 2:5.

20. Zoccali C., Mallamaci F., Parlongo S. et al., (2002): Plasma norepinephrine Predicts survrial and incident cardiovascular events in patients with end stage renal disease. Circulation 105:1345-1359. 


\section{تأثير الاستصفاء الاموي على نسب الكالسيوم و الفوسفور والماغنسيوم أثناء

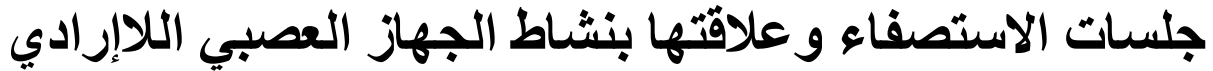

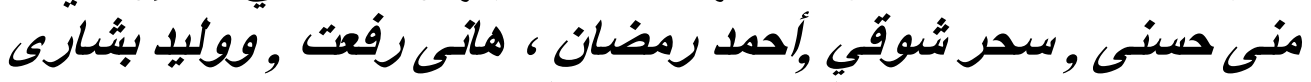 قسم الباطنّة العامة , كلية طب عين شمس في رفس}

يشيع الاختلال الوظيفي للجهاز العصبي الـاإرادي في مرضسى الفشل الكلوي و المرضسى الذين

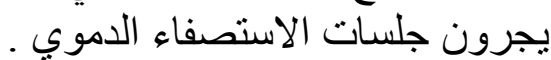

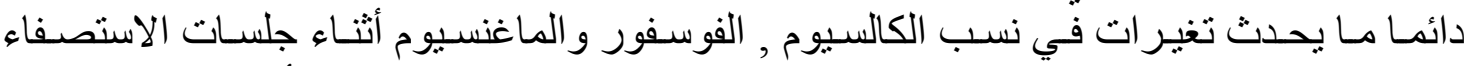

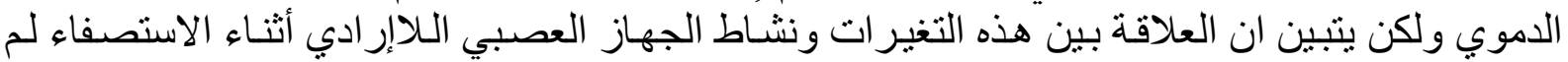

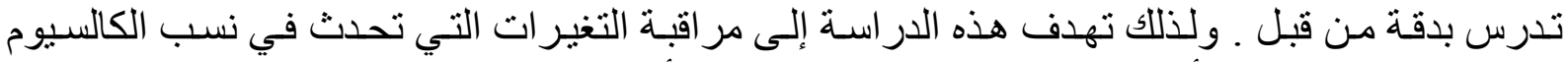

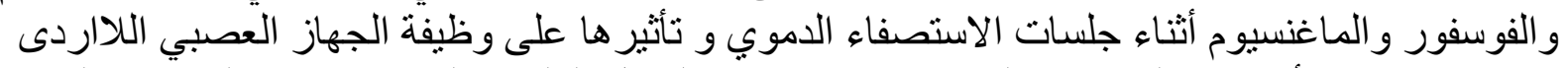

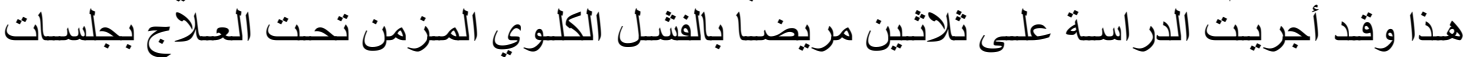

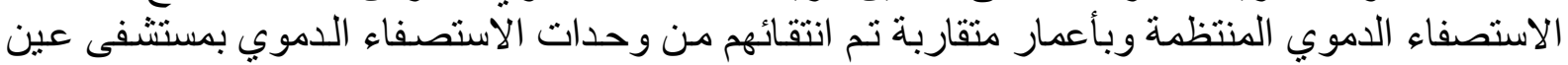

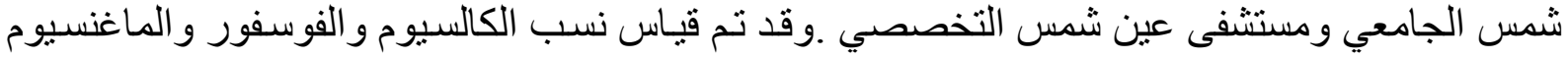
قبل وفى منتصف وبعد إتمام جلسات الاستصفاء الدموي كما تم عمل اختبار ات للجهاز العصبي الـإي إر ادي

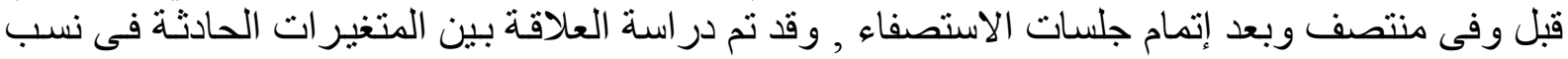

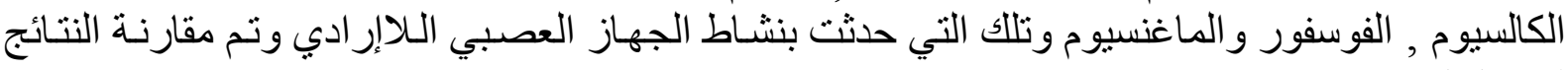

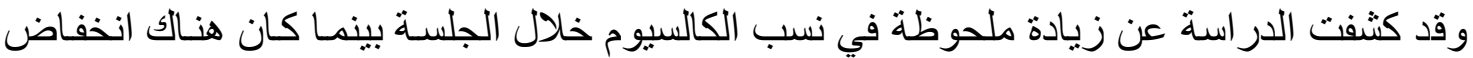

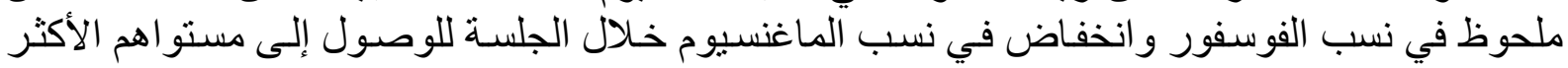

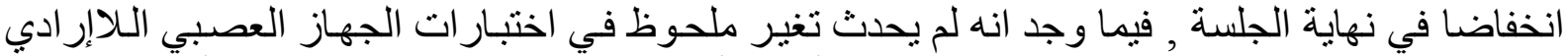

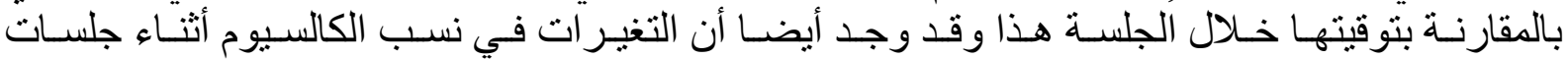

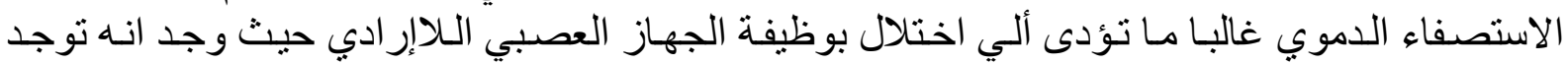

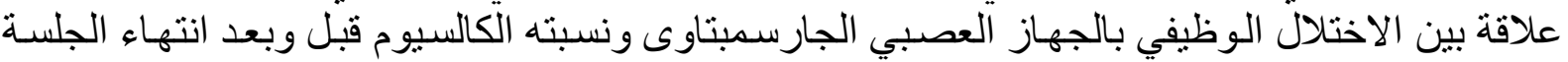

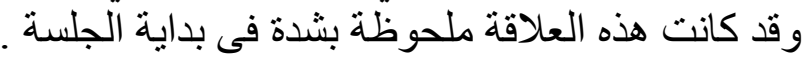

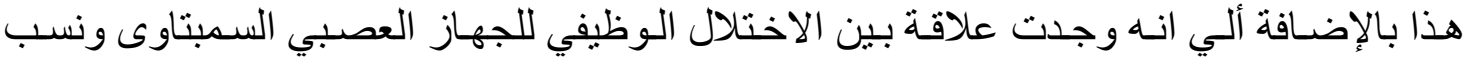

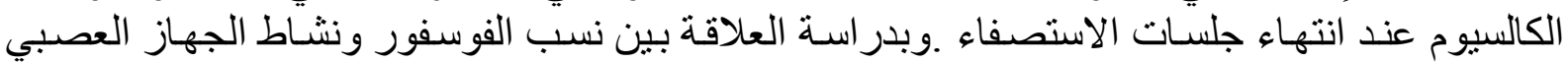

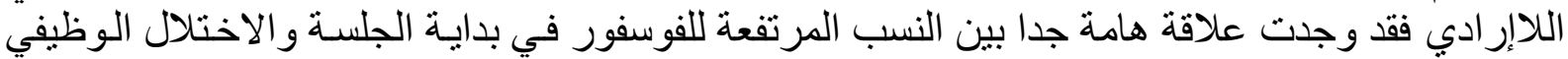

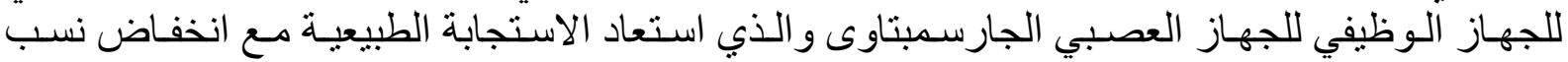

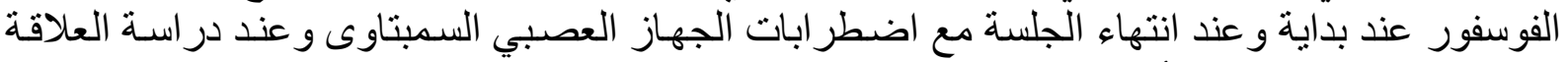

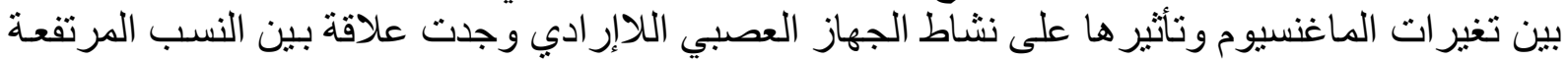

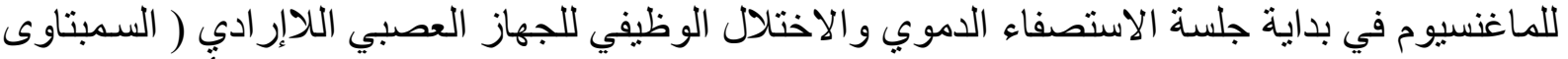

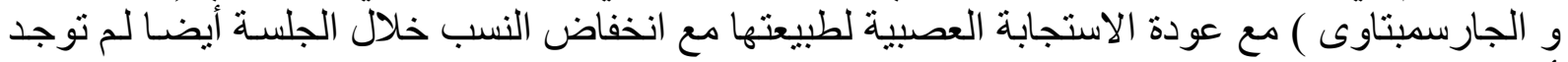

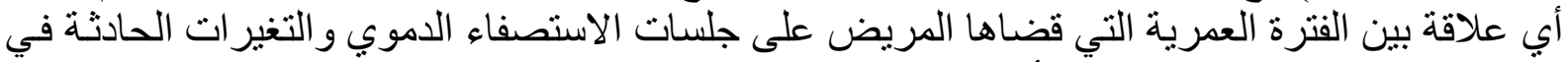

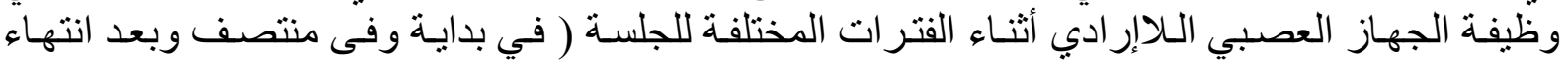

